\section{Prevalence of and Factors Associated with Actinic Cheilitis in Extractive Mining Workers}

Rafaelle Ferreira dos Santos ${ }^{1}$, Rogéria Lucio de Oliveira ${ }^{1}$, Marina Gallottini², Rubens Caliento ${ }^{2}$, Dmitry José de Santana Sarmento ${ }^{2}$
'Oral Diagnosis, UEPB -

Universidade Estadual da

Paraiba, Araruna, PB, Brazil

${ }^{2}$ Oral Pathology, USP - Universidade

de São Paulo, São Paulo, SP, Brazil

Correspondence: Dmitry José de Santana Sarmento, Av. Coronel Pedro

Targino, 58233-000 Araruna, PB, Brasil. Tel: +55-83-3373-1040. e-mail: dmitry_sarmento@hotmail.com

\begin{abstract}
The objective of the present study was to determine the prevalence of actinic cheilitis among extractive mining workers and factors associated with the condition, especially the relationship between clinical appearance and the length of occupational exposure to sunlight. A cross-sectional study was performed in Dona Inês, Paraiba, Brazil between 2014 and 2015. A clinical examination, clinical photography and a questionnaire were applied to 201 extractive mining workers. The T-student's, ANOVA one-way, Fisher's exact and Pearson chi-squared tests were performed and the significance level was set at $5 \%$. A high prevalence of actinic cheilitis was observed (38.8\%). Length of occupational exposure to sunlight in months $(169.63 \pm 112.68, p=0.002)$ was associated with actinic cheilitis. Most workers were Caucasian $(p<0.001)$ and aged $37.41 \pm 12.15$ years $(p=0.004)$. The time of occupational exposure to sunlight was significant in relation to the following clinical features: atrophy $(225.75 \pm 97.31 ; p=0.024)$; blurred demarcation between the vermilion border of the lip and the skin $(186.68 \pm 113.15 ; p=0.032)$; vertical fissures $(210.09 \pm 123.07$; $p=0.046) ;$ white and red spotting (199.51 $\pm 91.80 ; p=0.004)$; hard consistency of the lip $(225.81 \pm 122.34 ; p=0.012)$. A high prevalence of actinic cheilitis was found. Age and ethnicity were associated with the presence of AC. Severe clinical presentations of actinic cheilitis were found among participants who had worked for at least 185 months (approximately 15 years) exposed to the sun.
\end{abstract}

Key Words: actinic cheilitis, lip diseases, ultraviolet rays, epidemiologic studies

\section{Introduction}

Actinic cheilitis (AC) is a pre-malignant lesion that can develop into squamous cell cancer of the lip $(1,2)$, and is the most prevalent type of lip lesion. While the association between $\mathrm{AC}$ and squamous cell carcinoma (SCC) has been clearly established, its malignant transformation rate has yet to be agreed upon (3).

The main risk factor for the development of $A C$ is chronic and excessive exposure to ultraviolet (UV)radiation. This causes cumulative damage to the lip epithelium, interferes with the immune system through its effects on the skin-associated lymphoid tissues, suppresses contact hypersensitivity and delayed-type hypersensitivity, and induces the growth of the lesion $(4,5)$. A number of factors influence the emergence of $A C$, including genetic predisposition, skin color and age. Smoking, alcoholism and organ transplantation may increase its severity and result in the slight progression of the injury (6). Men with leukoderma, who are aged over 45 and have a history of chronic exposure to sunlight, are considered at risk for the development of AC. (3,7-9).

The prevalence of $A C$ reported in literature varies from $0.45 \%$ to $39.6 \%(10-15)$. The differences in these prevalences are due to the variations between the groups studied and the differing methodologies used by the authors. AC is presented as a diffuse lesion of the vermilion border of the lip, with variable clinical presentation (blurred demarcation between the vermilion border and the skin, scaling, vertical fissures, atrophy, erythema, spotting, white plaques and/or ulceration) $(7,12,14,15-17)$. The early diagnosis of $A C$ is of great importance in Brazil, due to the country's tropical climate and the fact that various economic activities (including fishing and agriculture) involve exposure to sunlight $(12,16,18,19)$.

This is the first study to assess the prevalence of AC among extractive mining workers. The objective of the study was to determine the prevalence of AC among such workers and factors associated with the condition, mainly the relationship between clinical characteristics, time of occupational exposure to sunlight, age, gender, ethnicity, smoking and knowledge about AC.

\section{Material and Methods}

A cross-sectional study was performed between 2014 and 2015 in Dona Inês in the state of Paraiba in northeastern Brazil. An inductive, quantitative method with statisticdescriptive procedures was used to survey extractive mining workers from an inner-city area in a tropical region of 
Brazil. The city of Dona Inês is located at an altitude of 480 meters above sea level and has a warm tropical climate. Its population is estimated to be 11,517 inhabitants and it has a low human development index (0.551). The municipality is included in the Brazilian semi-arid geographic region. The study was approved by the International Review Board (IRB) of the School of Dentistry of the Universidade Estadual da Paraiba (Paraiba State University), and all the workers who agreed to participate in the study signed a Free and Informed Consent Form.

The town has only one mining company with 395 extractive mining workers. It was therefore decided to invite all such workers to participate in the survey (census sample), with individuals agreeing to participate in the study through the signing of the consent form. Participants who were unable to perform the clinical examination were excluded. Of 395 workers, $49 \%$ refused to participate in the research, resulting in 201 participants.

Demographic (age, ethnicity, gender) and clinical (see definitions below) data were collected, while information about the length of occupational exposure to sunlight, use of alcohol and tobacco, knowledge about AC (including awareness of the relationship between lip cancer and $A C$ ), and forms of sunlight protection (if any) used by the participants were gathered by two previously calibrated investigators and recorded at the time of the clinical examination. This exam was performed at the workplace of the participating workers, in order to not disrupt their daily routine, and consisted of a visual inspection under ambient lighting following standard biosafety practices. The independent personal and employment variables analyzed were obtained from the completed questionnaire developed for this research, according to the studies of Cavalcante et al. (7), Junqueira et al. (12), Lucena et al. (13), Ribeiro et al. (16) and Souza Lucena et al. (17). The variables "age", "length of occupational exposure to sunlight", "use of alcohol and tobacco", "sunlight protection" and "knowledge about $\mathrm{AC}$ " were collected through a questionnaire applied by the calibrated investigators. The answers were inserted in an Excel table. The "gender" and "ethnicity" variables and the "clinical data" refer to the data collected by the researchers."

An AC lip lesion was defined as any abnormal change to the oral mucosa surface of the lip, including the following clinical characteristics: 1) scaling: the presence of flakes or scales caused by the desquamation of the stratum corneum; 2) vertical fissures: linear cleavages extending into the dermis; 3) atrophy: depression of the lip resulting from the thinning of the dermis or epidermis; 4) erythema: reddening of the lip caused by vasodilatation; 5) spotting: change of the color of the normal mucosa without border elevation or depression; 6) mottled appearance indicating the simultaneous presence of erythema and white patches; 7) plaque: a solid, raised, flat-topped lesion $>1 \mathrm{~cm}$ in diameter; 8) ulceration: disruption of the epithelium with exposed connective tissue; and 9) blurred demarcation between the vermilion border of the lip and the skin (16). Additionally, the presence on the lip of dryness, edema, lip consistency, surface alterations, lip involvement and the location of injuries were analyzed. Individuals with a severe form of these characteristics were considered for potential diagnosis of SCC $(12,18,19)$. Cases diagnosed as AC or suggestive of SCC were referred to a local cancer reference center for biopsies and suitable treatment.

The two researchers were calibrated in two stages. The first stage consisted of a discussion about AC and its clinical features and included a clinical image assessment. The second stage was the calibration itself, where both researchers individually performed the evaluation of 20 lip images with or without AC. These images were assessed by the same researchers 15 days after the first viewing. The intra-rater kappa values obtained were $\mathrm{k}=0.89$ (investigator 1) and $k=0.78$ (investigator 2) and the inter-rater kappa value was $k=0.72$. These values were considered satisfactory.

The Fisher's Exact and Pearson's chi-squared tests were used to compare the presence of AC with categorical variables such as ethnicity/skin color (Caucasian, Brownskinned/Mixed-race or Melanoderma), smoking (Yes or No), knowledge of AC (Yes or No) and use of protection against sunlight (Yes or No). The sample comprised only men and gender-related analysis was therefore not performed. The student's t-test and ANOVA one-way test were used to associate the quantitative variables "age (in years)" and "time of occupational exposure to sunlight (in months)" with the presence of $A C$, as well as to compare the time of occupational exposure to sunlight (in months) with the clinical features of AC. The significance level was set at $5 \%$ and the collected data was statistically analyzed using the SPSS 20.0 software for Windows (SPSS, Inc., Chicago, IL, USA).

\section{Results}

AC was diagnosed in $38.8 \%$ of the 201 participants (78 individuals). All the workers included in the present study were male. It was observed that mining workers with $\mathrm{AC}(37.41 \pm 12.15)$ were on average five years older than those without such lesions $(32.20 \pm 12.46)(p=0.004)$, $60.3 \%(n=47)$ of the sample were younger than 40 , and the majority were Caucasian $(57.7 \%, n=45 / 78, p<0.001)$. Regarding deleterious habits, most workers with $\mathrm{AC}(78.2 \%$, $\mathrm{n}=61 / 78$ ) reported having smoked and/or drunk alcohol, of which $32.1 \%(n=25 / 78)$ were current smokers. This finding was not associated with the presence of $A C(p=0.676)$. (Tables 1 and 2) 
When time of occupational exposure to sunlight was considered, it was observed that the presence of AC was associated with labor time in months $(169.63 \pm 112.68$, $p=0.002$ ) (Table 1). Time of occupational exposure to sunlight in hours ( $p=0.861)$, days per week $(p=0.308)$, time of exposure to sun between ten am and four pm ( $\mathrm{p}=0.872)$, and hours/week (0.372) and hours/month (0.309) of exposure to sun were not associated with the presence of AC.

Workers who reported being aware of forms of protection against $\mathrm{AC}$ had a lower prevalence of the disease, although the difference was not statistically significant $(p=0.111)$. Significant differences in the prevalence of AC were not observed among workers who said they had no knowledge of the relationship between exposure to sun and $A C(p=0.872)$ and lip cancer $(p=0.705)$ and those who said they knew about this relationship. Extractive mining workers who reported using some form of protection against solar radiation presented a lower prevalence

Table 1. Association between actinic cheilitis and age and length of occupational exposure to sunlight

\begin{tabular}{|c|c|c|c|c|}
\hline \multirow{2}{*}{ Variable } & \multirow{2}{*}{$\begin{array}{c}\text { Actinic } \\
\text { cheilitis }\end{array}$} & \multicolumn{2}{|r|}{ Descriptive } & \multirow{2}{*}{$\mathrm{p}^{(1)}$} \\
\hline & & $\mathrm{n}$ & Mean \pm SD & \\
\hline \multirow{2}{*}{ Age } & Yes & 78 & $37.41 \pm 12.15$ & \multirow{2}{*}{$0.004^{*}$} \\
\hline & No & 123 & $32.20 \pm 12.46$ & \\
\hline \multirow{2}{*}{$\begin{array}{l}\text { Length of occupational } \\
\text { exposure to sunlight } \\
\text { (months) }\end{array}$} & Yes & 78 & $169.63 \pm 112.68$ & \multirow{2}{*}{$0.002^{*}$} \\
\hline & No & 123 & $116.85 \pm 121.35$ & \\
\hline
\end{tabular}

Key: SD - Standard deviation. (*): Statistically significant results. (1): Student's t-test. of AC (38.4\%) than those who said they did not use such protection (45.5\%), although the difference was not statistically significant (0.753). (Table 3 ) The main forms of prevention were using a hat/cap $(n=171)$ and a palhoça (improvised individual protection made of straw constructed in the workplace) $(n=72)$. (Table 4)

The time of occupational exposure to sunlight in months presented a significant association with the following characteristics: lip atrophy $(225.75 \pm 97.31 ; p=0.024)$; blurred demarcation between the vermilion border of the lip and the skin $(186.68 \pm 113.15 ; p=0.032)$; vertical fissures $(210.09 \pm 123.07 ; p=0.046)$; white and red spotting $(199.51 \pm 91.80 ; p=0.004) ;$ and hard consistency of lip (225.81 $\pm 122.34 ; p=0.012)$. Additionally, patients with AC affecting the entire lip had an average of $214.07 \pm 110.51$ months of sunlight exposure at work $(p=0.017)$ (Table 5$)$. We have proposed a clinical classification based on the time of exposure to sunlight (Fig. 1).

\section{Discussion}

The Brazilian mining sector represents 5\% of the national PIB according to the Brazilian Mining Institute (IBRAM). The number of mining companies in the country was 8,870 in 2013, with 1,606 located in the northeast region, and the sector generates 214,070 direct jobs. Although Brazil is a world leader in this area, with large mining companies such as Vale do Rio Doce, there are smaller companies where worker care may be an issue. Most extractive mining workers are male and many perform their work exposed to the sun, often without any protection, which can lead to the appearance of chronic injuries such as AC.

The aim of the present study was to determine the prevalence of $\mathrm{AC}$ among extractive mining workers and the relationship between the condition and epidemiological characteristics, working time and the knowledge of individuals about the lesion. A high prevalence of AC was observed (78/201; $38.8 \%)$, a finding which was similar to that of a study by Junqueira et al. (12), which found a prevalence of AC of $39.6 \%$ among farmers in a tropical area of Brazil. A study performed by Araújo et al. (10) observed a lower prevalence $(2 / 395 ; 0.5 \%)$, although the sample in this study was composed of police officers. These authors explained the low prevalence among this group by a greater understanding of the risks of excessive exposure to the sun among the sample population, as well as a lower exposure time.

The majority of the sample of the present study was Caucasian and aged below 40. All participants were male, which can be attributed to the fact that this work is more common among

(*): Statistically significant results. (1): Pearson's Chi-squared test. 
men due to the physical effort required. These findings agree with studies by Markopoulos et al. (20), Cavalcante et al. (7), Lucena et al. (13), Miranda et al. (15), Sarmento et al. (5) and Gheno et al. (21), other than for age, as most of these surveys identified a mean age of above 40 . The difference in the data suggests that the risk group assessed in the present study develops AC at an earlier stage, possibly due to earlier and more excessive exposure to sunlight. It was additionally observed that the mean age of workers with $A C$ was higher than those without the lesion. This difference was statistically significant, corroborating other studies which demonstrated a relationship between AC and age $(13,16)$.

The studies by Martins-Filho et al. (14) and Miranda et

Table 3. Association between actinic cheilitis and knowledge of workers about AC and variables related to the use of sunlight protection

\begin{tabular}{|c|c|c|c|c|c|}
\hline \multirow[b]{2}{*}{ Variable } & & \multicolumn{2}{|c|}{ Actinic cheilitis } & \multirow[b]{2}{*}{ Total } & \multirow[b]{2}{*}{$\mathrm{p}$} \\
\hline & & $\begin{array}{l}\text { Yes } \\
\mathrm{n}(\%)\end{array}$ & $\begin{array}{l}\text { No } \\
\mathrm{n}(\%)\end{array}$ & & \\
\hline \multirow{2}{*}{ Knowledge about forms of protection } & Yes & $73(37.6)$ & $121(62.4)$ & 194(100) & \multirow{2}{*}{$0.111^{(1)}$} \\
\hline & No & $5(71.4)$ & $2(28.6)$ & $7(100)$ & \\
\hline \multirow{2}{*}{$\begin{array}{l}\text { Knowledge about relationship } \\
\text { between exposure to sun and AC }\end{array}$} & Yes & $61(39.1)$ & $95(60.9)$ & $156(100)$ & \multirow{2}{*}{$0.872^{(2)}$} \\
\hline & No & $17(37.8)$ & $28(62.2)$ & $45(100)$ & \\
\hline \multirow{2}{*}{$\begin{array}{l}\text { Knowledge about relationship } \\
\text { between lip cancer and lip lesion }\end{array}$} & Yes & $54(39.8)$ & $82(60.2)$ & $136(100)$ & \multirow{2}{*}{$0.705^{(2)}$} \\
\hline & No & 24(36.9) & $41(63.1)$ & $65(100)$ & \\
\hline \multirow{2}{*}{ Use any form of protection } & Yes & $73(38.4)$ & $117(61.6)$ & 190(100) & \multirow{2}{*}{$0.753^{(1)}$} \\
\hline & No & $5(45.5)$ & $6(54.5)$ & $11(100)$ & \\
\hline Total & & 78 (38.8) & $123(61.2)$ & $201(100.0)$ & \\
\hline
\end{tabular}

Table 4. Association between actinic cheilitis and forms of protection used by workers

\begin{tabular}{|c|c|c|c|c|c|}
\hline \multirow[b]{2}{*}{ Variable } & & \multicolumn{2}{|c|}{ Actinic cheilitis } & \multirow[b]{2}{*}{ Total } & \multirow[b]{2}{*}{$\mathrm{p}$} \\
\hline & & $\begin{array}{l}\text { Yes } \\
\mathrm{n}(\%)\end{array}$ & $\begin{array}{c}\text { No } \\
\mathrm{n}(\%)\end{array}$ & & \\
\hline \multirow{2}{*}{ Sunlight protection } & Yes & $27(45.8)$ & $32(54.2)$ & $59(100)$ & \multirow{2}{*}{$0.163^{(1)}$} \\
\hline & No & $46(35.1)$ & $85(64.9)$ & $131(100)$ & \\
\hline \multirow{2}{*}{ Lip protector } & Yes & $11(57.9)$ & $8(42.1)$ & $19(100)$ & \multirow{2}{*}{$0.066^{12}$} \\
\hline & No & $62(36.2)$ & 109(63.8) & $171(100)$ & \\
\hline \multirow{2}{*}{ Hat/Cap } & Yes & $68(39.8)$ & $103(60.2)$ & $171(100)$ & \multirow{2}{*}{$0.253^{(1)}$} \\
\hline & No & $5(26.3)$ & $14(73.7)$ & $19(100)$ & \\
\hline \multirow{2}{*}{ Palhoça* } & Yes & $29(40.3)$ & $43(59.7)$ & $72(100)$ & \multirow{2}{*}{$0.681^{(1}$} \\
\hline & No & $44(37.3)$ & $74(62.7)$ & $118(100)$ & \\
\hline Total & & $73(38.4)$ & 117 (61.6) & $190(100)$ & \\
\hline
\end{tabular}

(1): Fisher's exact test. (2): Pearson's Chi-squared test. *Palhoça is an improvised individual protection made of straw constructed in the workplace. 
al. (15) identified a high incidence of exposure to sunlight among the assessed population, and found a significant association between exposure to sunlight and AC. This data was also observed in the present survey, where it was found that working time in months was associated with
$\mathrm{AC}$, as the extractive mining workers with $\mathrm{AC}$ had worked under exposure to sunlight for an average of 170 months. It can therefore be inferred that an average of 14 years of working under exposure to sunlight is related to the clinical presence of AC. Furthermore, there was no significant

Table 5. Comparison between the length of exposure to sun in months and the clinical aspects of actinic cheilitis

\begin{tabular}{|c|c|c|c|c|}
\hline \multirow{2}{*}{ Clinical features } & & \multicolumn{2}{|c|}{ Time of occupational exposure to sunlight (months) } & \multirow{2}{*}{$\mathrm{p}$} \\
\hline & & $\mathrm{n}$ & mean \pm SD & \\
\hline \multirow{2}{*}{ Dryness } & Yes & 64 & $169.72 \pm 114.80$ & \multirow{2}{*}{$0.988^{(1)}$} \\
\hline & No & 14 & $169.21 \pm 106.46$ & \\
\hline \multirow{2}{*}{ Atrophy } & Yes & 16 & $225.75 \pm 97.31$ & \multirow{2}{*}{$0.024^{(1) *}$} \\
\hline & No & 62 & $155.15 \pm 112.11$ & \\
\hline \multirow{2}{*}{ Edema } & Yes & 21 & $155.48 \pm 121.51$ & \multirow{2}{*}{$0.504^{(1)}$} \\
\hline & No & 57 & $174.84 \pm 109.91$ & \\
\hline \multirow{2}{*}{$\begin{array}{l}\text { Blurred demarcation between the } \\
\text { vermilion border of the lip and the skin }\end{array}$} & Yes & 56 & $186.68 \pm 113.15$ & \multirow{2}{*}{$0.032^{(1) *}$} \\
\hline & No & 22 & $126.23 \pm 101.34$ & \\
\hline \multirow{2}{*}{ Ulceration } & Yes & 7 & $225.86 \pm 121.17$ & \multirow{2}{*}{$0.168^{(1)}$} \\
\hline & No & 71 & $164.08 \pm 111.17$ & \\
\hline \multirow{2}{*}{ Scaling } & Yes & 19 & $178.74 \pm 124.18$ & \multirow{2}{*}{$0.688^{(1)}$} \\
\hline & No & 59 & $166.69 \pm 109.70$ & \\
\hline \multirow{2}{*}{ Vertical fissures } & Yes & 22 & $210.09 \pm 123.07$ & \multirow{2}{*}{$0.046^{(1) *}$} \\
\hline & No & 56 & $153.73 \pm 105.26$ & \\
\hline \multirow{2}{*}{ Erythema } & Yes & 48 & $166.79 \pm 102.13$ & \multirow{2}{*}{$0.792^{(1)}$} \\
\hline & No & 30 & $174.17 \pm 129.50$ & \\
\hline \multirow{4}{*}{ Spotting } & White & 24 & $189.29 \pm 135.86$ & \multirow{4}{*}{$0.004^{(2)^{*}}$} \\
\hline & White and red & 35 & $199.51 \pm 91.80$ & \\
\hline & Red & 13 & $85.92 \pm 65.95$ & \\
\hline & Brownish & 6 & $98.00 \pm 101.94$ & \\
\hline \multirow{3}{*}{ Consistency of lip } & Flaccid & 29 & $166.79 \pm 99.79$ & \multirow{3}{*}{$0.012^{(2) *}$} \\
\hline & Hard & 21 & $225.81 \pm 122.34$ & \\
\hline & Normal & 28 & $130.43 \pm 103.62$ & \\
\hline \multirow{3}{*}{ Surface of lip } & Crustose & 04 & $105.00 \pm 11.48$ & \multirow{3}{*}{$0.300^{(2)}$} \\
\hline & Corrugated & 45 & $183.89 \pm 114.80$ & \\
\hline & Smooth & 29 & $156.41 \pm 114.39$ & \\
\hline \multirow{3}{*}{ Lip involvement } & 1/3 of lip & 31 & $135+13 \pm 106.33$ & \multirow{3}{*}{$0.017^{(2) *}$} \\
\hline & $1 / 2$ of lip & 17 & $154.12 \pm 107.24$ & \\
\hline & All of lip & 30 & $214.07 \pm 110.51$ & \\
\hline \multirow{2}{*}{ Localization } & Lower lip & 68 & $168.46 \pm 114.30$ & \multirow{2}{*}{$0.812^{(2)}$} \\
\hline & Upper and lower lip & 10 & $177.60 \pm 106.25$ & \\
\hline
\end{tabular}

Subtitle: SD - Standard deviation. ("): Statistically significant results. ${ }^{(1)}$ : Student's t-test. ${ }^{(2)}$ : ANOVA one-way. 
association between working day in hours (daily, weekly and monthly) and the presence of AC. Frequency in months appeared to be more important than time of exposure per day, a finding which can be explained by the chronic and cumulative character of $A C$, requiring an assessment of the effects of long-term exposure to sunlight.

A high prevalence of smokers was also observed among extractive mining workers with AC. Similar results were also found in a survey conducted by Piñera-Marques et al. (19). In contrast with these data, however, the present study failed to identify a significant association between smoking and the incidence of AC. This corroborates other studies by Jadotte and Schwartz (6) and Lopes et al. (22), which proposed that tobacco use should not be considered a determinant risk factor for $\mathrm{AC}$, but can be considered a contributive factor to the progression of an established lesion. It is important to mention that the non-association between smoking and $\mathrm{AC}$ may have been a false-negative result due to sample size, since the present study did not perform sample calculations and there was a high refusal rate among the extractive mining workers regarding participation in the survey. However, our data confirm that smoking is not the main etiological agent for AC.

Despite the clinical characterization of AC following defined parameters such as the loss of lip definition and atrophy, ulcerations or erythema $(12,18,19)$, the assessment of the condition remains subjective. Most time-based studies report only the main clinical features observed in $A C$, without associating such characteristics with the time of solar exposure $(14,16)$.

The present study associated the presence of clinical alterations with the length of time of occupational exposure to sunlight. It was observed that lesions found in individuals who were more exposed to the sun were characterized by atrophy, blurred demarcation between the vermilion border of the lip and the skin, vertical fissures, white and red spots, hard lip consistency, a corrugated surface and ulceration. In addition, the full involvement of the lip in these characteristics should be considered when evaluating severity. Considering that sun damage is cumulative for $\mathrm{AC}$, more serious injuries may be related to time of exposure to the sun. This allows us to suggest a "clinical classification" where lesions with the above characteristics are more aggressive. All these aggressive abnormalities were present in patients with at least 185 months (approximately 15 years) of exposure to the sun. On the other hand, participants with less than 185 months of exposure had dryness, edema, scaling, erythema, brownish spots, flaccid or normal consistency of the lip, a smooth or crusty surface and $1 / 2$ or $1 / 3$ lip involvement. These characteristics clinically define a less aggressive AC.

When the knowledge of mining workers about $A C$ was assessed via the three previously cited questions, most workers declared that they had knowledge of prevention methods. Despite this, a high prevalence of this lesion was found among such workers. This suggests that having knowledge about the disease does not result in the adoption of preventive habits. However, more specific studies to confirm this hypothesis are required. Correa et al. (23) found TP53 missense mutations in AC, including $\mathrm{CC}>\Pi$ transitions, a marker of UV damage. The loss of heterozygosity and TP53 mutations detected in AC may therefore be associated with tumorigenesis. Depending on when knowledge is acquired and on the solar protection used by workers, therefore, the protective effect may be limited as the mutation may already be installed. The prevention of $\mathrm{AC}$ should therefore begin before exposure to sunlight and the emergence of the mutation.

Gheno et al. (21) evaluated the association between the frequency of oral mucosal lesions and demographic, social, health and behavioral factors, and observed a significant association between the presence of $\mathrm{AC}$ and low levels of
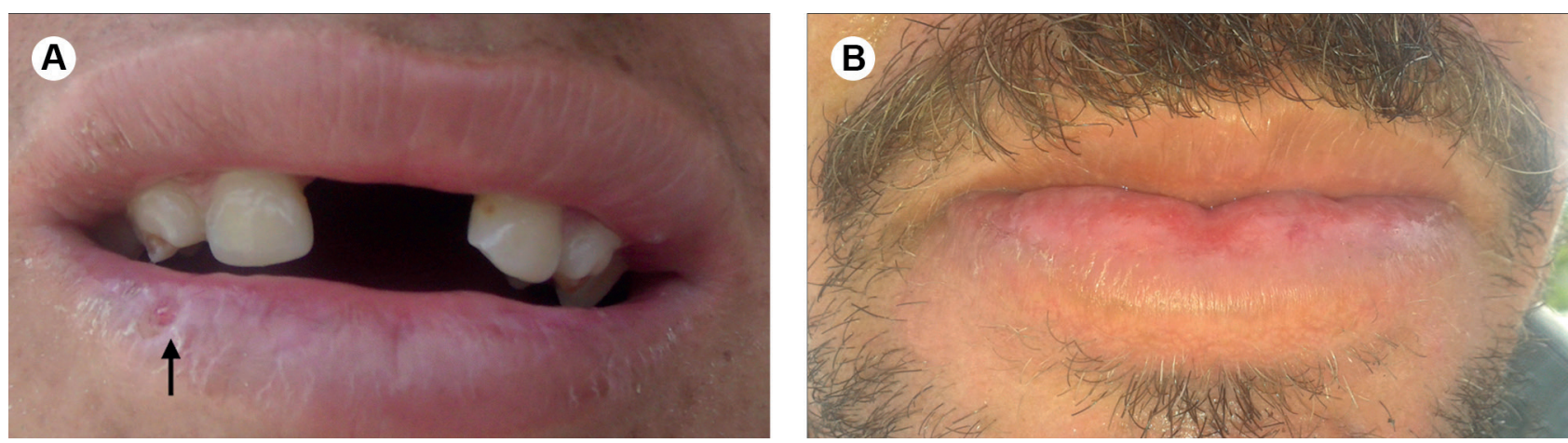

Figure 1. Clinical classification according to length of exposure to sunlight. A. Patient with actinic cheilitis showing partial blurred demarcation between vermilion border of lip and skin and ulceration. Lip consistency of patient was hard. B. Patient with actinic cheilitis showing dryness, edema and erythema. Patient had flaccid consistency and a smooth lip surface. 
education. Literacy is directly correlated with access to education. This can explain the fact that individuals who reported not being aware of forms of protection against $\mathrm{AC}$ were, proportionally, more likely to be illiterate. Lucena et al. (13) found that individuals diagnosed with AC had a slightly lower level of schooling, education and monthly income than those without the injury, showing that such aspects can affect the incidence of AC.

Most extractive workers reported using preventive measures against $\mathrm{AC}$, with a hat/cap the most frequently used. Similar data was observed by Lucena et al. (13) where the use of a hat/cap was also the most reported form of protection used. However, this study identified a relationship between using such protection and the presence of lip lesions due to exposure to the sun.

Martins-Filho et al. (14) observed that the use of a cloth on the head as protection against exposure to the sun was associated with a lower incidence of AC. This finding does not corroborate the findings of the present study, where it was observed that protective aids were not significantly associated with the presence of lip lesions.

The results of the present study are important for guiding the implementation of public measures aimed at the awareness and information of the population at risk, starting with a diagnosis campaign to show that AC deserves special attention from the general population, malignance potential. While the present study is the first to assess the presence of $A C$ among extractive mining workers, such surveys are essential to provide updated information about $A C$, its prevalence, main risk factors and forms of prevention. It was observed that the severity of the injury was proportional to the duration of occupational exposure to sunlight, suggesting a clinical classification for AC. It is important to mention that the present crosssectional study presents certain limitations that should be considered, such as sample calculation, participant response rate, validation of questionnaires and bivariate statistical analysis. Controlled studies, with a sample calculation that represents a larger portion of the population of extractive mining workers, should be performed, so that the results observed in the present study can be corroborated.

In summary, a high prevalence of AC was found, especially in Caucasian men with a long period of occupational exposure to sunlight. Age and ethnicity were associated with the presence of AC. The most severe clinical changes to the lip were found in workers who had suffered at least 185 months (approximately 15 years) of exposure to sunlight when working, suggesting a clinical classification for AC. Knowledge of AC among this group and protection against exposure to the sun did not affect the occurrence of $A C$ in this population.

\section{Resumo}

0 objetivo foi determinar a prevalência de queilite actínica entre os trabalhadores extrativistas minerais e os fatores associados a esta lesão, principalmente a relação da aparência clínica da lesão com o tempo de exposição ocupacional à luz solar. Foi realizado um estudo transversal, entre 2014 e 2015, em Dona Inês / PB, localizado no Nordeste do Brasil. Foram aplicados um exame clínico, registro fotográfico e um questionário a 201 trabalhadores extrativistas minerais. Realizaramse os testes " $t$ " student, ANOVA, Exato de Fisher e Qui-quadrado de Pearson, o nivel de significância foi de $5 \%$. Observou-se alta prevalência de queilite actínica (38,8\%). A duração da exposição ocupacional à luz solar, em meses, $(169,63 \pm 112,68, p=0,002)$ foi associada à presença de queilite actínica. Estes trabalhadores eram, em sua maioria, brancos $(p<0.001)$ com idade média de $37.41 \pm 12.15$ anos $(p=0.004)$. 0 tempo de exposição ocupacional à luz solar foi significativo em relação às seguintes características clínicas: atrofia $(225,75 \pm 97,31 ; p=0,024)$; perda da demarcação entre o vermelhão do lábio e a borda da pele $(186,68 \pm 113,15 ; p=0,032) ;$ Fissuras verticais $(210,09 \pm 123,07 ; p=$ $0,046)$; Manchas brancas e vermelhas $(199,51 \pm 91,80 ; p=0,004)$; Consistência dura do lábio $(225,81 \pm 122,34 ; p=0,012)$. Conclui-se que a prevalência de queilite actínica foi alta. A idade e a etnia foram fatores associados a presença de queilite actinica. Os participantes que haviam trabalhado pelo menos 185 meses (aproximadamente 15 anos) sob exposição ao sol, apresentaram manifestações clínicas graves da queilite actínica.

\section{References}

1. Freitas MC, Ramalho LM, Xavier FC, Moreira AL, Reis SR. p53 and MDM2 protein expression in actinic cheilitis. J Appl Oral Sci 2008;6:414-419.

2. Miranda AM, Ferrari T, Leite T, Domingos T, Cunha K, Dias E. Value of videoroscopy in the detection of alterations od actinic cheilitis and the selection of biopsy areas. Med Oral Patol Oral Cir Bucal 2015;20:292-297.

3. Barrado Solís N, Molés Poveda P, Lloret Ruiz C, Pont Sanjuan V, Velasco Pastor M, Quecedo Estébanez E et al. Ingenol mebutate gel treatment for actinic cheilitis: report of four cases. Dermatol Ther 2015;28:79-82.

4. Araújo $C P$, Gurgel CA, Ramos EA, Freitas VS, Barbosa A de A Jr, Ramalho LM et al. Accumulation of CD1a positive Langerhans cells and mast cells in actinic cheilitis. J Mol Histol 2010;41:357-365.

5. Sarmento DJS, da Costa Miguel MC, Queiroz LM, Godoy GP, da Silveira EJ. Actinic cheilitis: clinicopathologic profile and association with degree of dysplasia. Int J Dermatol 2014;53:466-472.

6. Jadotte YT, Schwartz RA. Solar cheilosis: an ominous precursor: part I. Diagnostic insights. J Am Acad Dermatol 2012;66:173-184.

7. Cavalcante $A S$, Anbinder AL, Carvalho YR. Actinic cheilitis: clinical and histological features. J Oral Maxillofac Surg 2008;66:498-503.

8. Bertini F, Sgarbi FC, Tera TM, Brandão AAH, Cavalcante ASR. Histological analysis of the actinic cheilitis: an interobserver approach. Int J Dent 2010;9:6-10.

9. Calcaianu N, Popescu SA, Diveica D, Lascar I. Surgical attitude in premalignant lesions and malignant tumors of the lower lip. J Med Life 2015;8:109-111.

10. Araújo VS, Godinho EL, Farias LC, Marques-Silva L, Santos SH, Rodrigues-Neto JF et al. Prevalence of oral mucosal lesions in a brazilian military police population. J Clin Exp Dent 2015;7:e208-211.

11. Corso FM, Wild C, Gouveia LO, Ribas MO. Actinic cheilitis: prevalence in the Oral Medicine Clinics of the PUCPR, Curitiba, PR, Brazil. Clin Pesq Odontol 2006;2:277-281.

12. Junqueira $J \mathrm{~L}$, Bönecker $M$, Furuse $C$, Morais Pde C, Flório FM, Cury PR et al. Actinic cheilitis among agricultural workers in Campinas, Brazil. Community Dent Health 2011;28:60-63.

13. Lucena EE, Costa DC, Silveira É, Lima KC. Prevalence and factors associated with orolabial lesions in beach workers. Rev Saude Publica 2012;46:1051-1057. 
14. Martins-Filho PR, Da Silva LC, Piva MR. The prevalence of actinic cheilitis in farmers in a semi-arid northeastern region of Brasil. Int J Dermatol 2011;50:1109-1114.

15. Miranda AM, Soares LG, Ferrari TM, Silva DG, Falabella ME, Tinoco EM. Prevalence of actinic cheilitis in a population of agricultural sugarcane workers. Acta Odontol Latinoam 2012;25:201-206.

16. de Oliveira Ribeiro A, da Silva LC, Martins-Filho PR. Prevalence of and risk factors for actinic cheilitis in Brazilian fishermen and women. Int J Dermatol 2014;53:1370-1376.

17. de Souza Lucena EE, Costa DC, da Silveira EJ, Lima KC. Prevalence and factors associeated to actinic cheilitis in beach workers. Oral Dis 2012;18:575-579.

18. Cataldo E, Doku HC. Solar cheilitis. J Dermatol Surg Oncol 1981;7:989-995.

19. Piñera-Marques K, Lorenço SV, Silva LF, Sotto MN, Carneiro PC. Actinic lesions in fishermen's lower lip: clinical, cytopathological and histopathologic analysis. Clinics 2010;65:363-367.

20. Markopoulos A, Albanidou-Farmaki E, Kayavis I. Actinic cheilitis: clinical and pathological characteristics in 65 cases. Oral Dis 2004; 10:212-216

21. Gheno JN, Martins MA, Munerato MC, Hugo FN, Sant'ana Filho M, Weissheimer $\mathrm{C}$ et al. Oral mucosal lesions and their association with sociodemographic, behavioral, and health status factors Braz Oral Res 2015;29:1-6.

22. Lopes $\mathrm{ML}$, Silva Júnior $\mathrm{FL}$, Lima KC, Oliveira PT, Silveira ÉJ Clinicopathological profile and management of 161 cases of actinic cheilitis. An Bras Dermatol 2015;90:505-512.

23. Correa GT, Bernardes VF, de Sousa SF, Diniz MG, Salles JM, Souza RP et al. Lip cancer and pre-cancerous lesions harbor TP53 mutations, exhibit allelic loss at 9p, 9q, and 17p, but no BRAFV600E mutations. Tumour Biol 2015;36:9059-9066.

Received September 13, 2017 Accepted November 29, 2017 